February 2005 - NREL/CP-520-37479

\title{
Enhanced-Depletion-Width GalnNAs Solar Cells Grown by Molecular-Beam Epitaxy
}

A.J. Ptak, D.J. Friedman, S. Kurtz, and J. Kiehl

Prepared for the $31^{\text {st }}$ IEEE Photovoltaics Specialists Conference and Exhibition

Lake Buena Vista, Florida

January 3-7, 2005
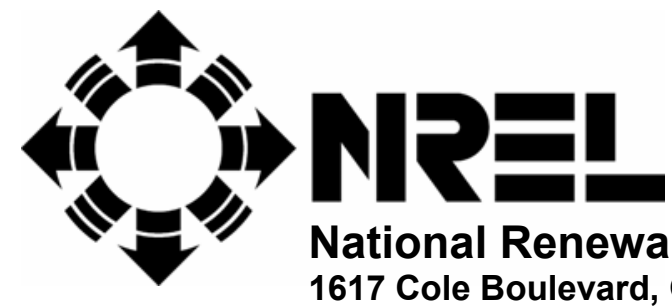

National Renewable Energy Laboratory 1617 Cole Boulevard, Golden, Colorado 80401-3393 303-275-3000 • www.nrel.gov

Operated for the U.S. Department of Energy

Office of Energy Efficiency and Renewable Energy

by Midwest Research Institute $\bullet$ Battelle

Contract No. DE-AC36-99-G010337 


\section{NOTICE}

The submitted manuscript has been offered by an employee of the Midwest Research Institute (MRI), a contractor of the US Government under Contract No. DE-AC36-99G010337. Accordingly, the US Government and MRI retain a nonexclusive royalty-free license to publish or reproduce the published form of this contribution, or allow others to do so, for US Government purposes.

This report was prepared as an account of work sponsored by an agency of the United States government. Neither the United States government nor any agency thereof, nor any of their employees, makes any warranty, express or implied, or assumes any legal liability or responsibility for the accuracy, completeness, or usefulness of any information, apparatus, product, or process disclosed, or represents that its use would not infringe privately owned rights. Reference herein to any specific commercial product, process, or service by trade name, trademark, manufacturer, or otherwise does not necessarily constitute or imply its endorsement, recommendation, or favoring by the United States government or any agency thereof. The views and opinions of authors expressed herein do not necessarily state or reflect those of the United States government or any agency thereof.

Available electronically at http://www.osti.gov/bridge

Available for a processing fee to U.S. Department of Energy and its contractors, in paper, from:

U.S. Department of Energy

Office of Scientific and Technical Information

P.O. Box 62

Oak Ridge, TN 37831-0062

phone: 865.576 .8401

fax: 865.576.5728

email: mailto:reports@adonis.osti.gov

Available for sale to the public, in paper, from:

U.S. Department of Commerce

National Technical Information Service

5285 Port Royal Road

Springfield, VA 22161

phone: 800.553 .6847

fax: 703.605.6900

email: orders@ntis.fedworld.gov

online ordering: http://www.ntis.gov/ordering.htm 


\title{
ENHANCED-DEPLETION-WIDTH GaInNAs SOLAR CELLS GROWN BY MOLECULAR- BEAM EPITAXY
}

\author{
Aaron J. Ptak, Daniel J. Friedman, Sarah Kurtz and James Kiehl \\ National Renewable Energy Laboratory, Golden, CO 80401
}

\begin{abstract}
GalnNAs, potentially useful in a 4-junction $\mathrm{GalnP}_{2} / \mathrm{GaAs} / \mathrm{GalnNAs} / \mathrm{Ge}$ solar cell, suffers from very low minority-carrier collection lengths. To date, the currents available from GalnNAs solar cells are not high enough to increase the efficiency of a 3-junction device by adding this fourth junction. Here, we grow p-i-n GalnNAs solar cells by MBE with wide, intrinsic base layers and internal QE's near 1.0. If similar 1.0-eV GalnNAs junctions can be successfully integrated into the 3-junction structure, the resulting 4junction cell would have a higher efficiency.
\end{abstract}

\section{INTRODUCTION}

The 3 -junction, GalnP $/ \mathrm{GaAs}_{2} / \mathrm{Ge}$ solar cell is a nonoptimized structure due to excess light absorbed by the $\mathrm{Ge}$ junction. Because of this, a fourth junction inserted between the GaAs and Ge subcells could use the excess light and provide an increase in device efficiency [1]. Unfortunately, the leading candidate material, $\mathrm{Ga}_{1-3 x} \mathrm{In}_{3 x} \mathrm{~N}_{\mathrm{x}} A s_{1-\mathrm{x}}$, hereafter GalnNAs, suffers from very low minority-carrier diffusion lengths compared to its parent compound, GaAs [2],[3]. These low diffusion lengths do not allow for the collection of adequate photocurrent to increase the efficiency of a 4-junction device to more than that of a 3-junction structure. If the photocurrents generated from the GalnNAs subcell are increased, practical conversion efficiencies from this structure may exceed $40 \%$.

Defects in the GalnNAs layer lead to short lifetimes for minority carriers. This means that diffusion lengths in this material are not long enough to generate significant photocurrent. One way to accomplish an increase of current from the GalnNAs junction is to employ a $p-i-n$ structure with a wide, intrinsic base layer. The built-in field across this depleted layer sweeps minority carriers toward the junction, increasing the current generated by the cell. Figure 1 shows modeled internal quantum efficiency (QE) values for $1.05 \mathrm{eV}$ bandgap GalnNAs solar cells with different thicknesses of the intrinsic base layer, or depletion layer. The model assumes that there is no collection from the GaAs emitter and no contribution due to diffusion in the GalnNAs base and that all carriers in the depleted layer are collected. Clearly, the QE is expected to improve dramatically with wider depletion widths. We estimate that photocarrier collection (drift plus any potential contribution from diffusion) from a region greater than $2 \mu \mathrm{m}$ is necessary for a GalnNAs

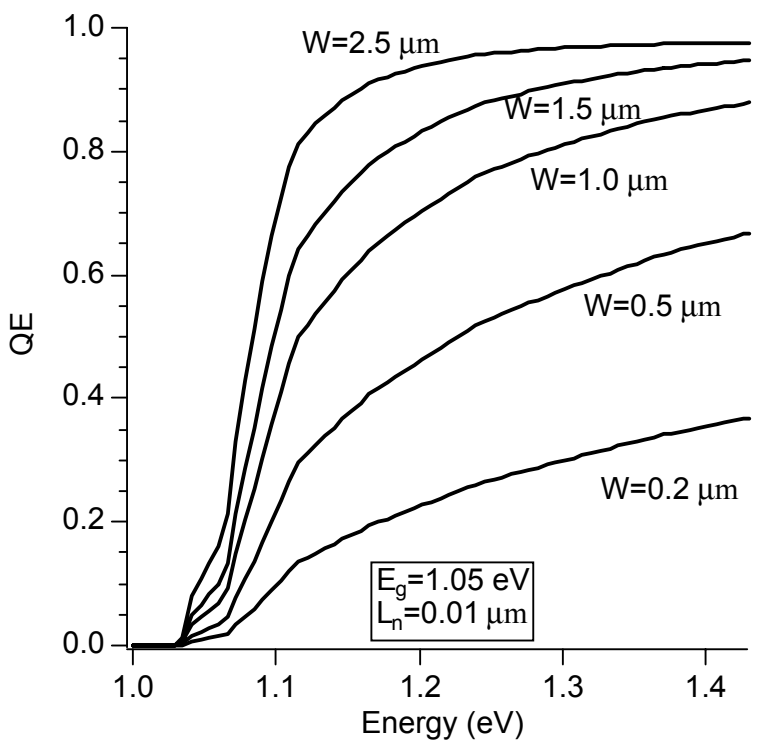

Figure 1. Calculations for GalnNAs solar cells with bandgaps of $\sim 1.05 \mathrm{eV}$, showing an increase of the internal quantum efficiency with increasing depletion width, $W$, for a base thickness of $3 \mu \mathrm{m}$.

cell with a bandgap near $1 \mathrm{eV}$ to provide an increased efficiency over the 3-junction device [4].

\section{Growth of GalnNAs by MBE}

Collection of sufficient photocarriers from outside the depletion region in GalnNAs is not assured because diffusion lengths are low. To make use of field-aided collection in the depletion region, a $\mathrm{p}-\mathrm{i}-\mathrm{n}$ structure requires a thick base layer with a very low background acceptor concentration. Unfortunately, GalnNAs grown by metalorganic chemical-vapor deposition (MOCVD) typically shows background carrier concentrations near $10^{17} \mathrm{~cm}^{-3}$ [5], with corresponding depletion widths of $\sim 0.2 \mu \mathrm{m}$. Carbon acceptors incorporated from the organic precursors used in MOCVD account for much of this high background level. The rest is likely due to gallium vacancies that are stabilized in GalnNAs by the abundant atomic hydrogen available during growth [6]. A positron annihilation spectroscopy report [7] shows that gallium vacancies are more likely to form in MOCVD-grown GalnNAs than in material grown by molecu- 
lar-beam epitaxy (MBE) due to the lack of hydrogen present during MBE growth. Also, MBE uses carbon-free sources, thus minimizing background impurities in addition to gallium vacancies. As a result, material grown by MBE has the potential for much lower background acceptor concentrations resulting in depletion widths of several microns.

\section{EXPERMINENTAL DETAILS}

GalnNAs solar cells were grown by solid-source MBE using elemental sources of $\mathrm{Ga}, \mathrm{In}$, and As, with active nitrogen provided by an Oxford HD25 rf-plasma source. The growth temperature for the nitride layers was $\sim 530^{\circ} \mathrm{C}$ and no post-growth annealing was performed. GaAs cells were grown for comparison at a temperature of $\sim 580^{\circ} \mathrm{C}$. For these experiments, the solar cells consist of an unintentionally doped GalnNAs, $3 \mu \mathrm{m}$ thick base layer and a Si-doped GaAs emitter $\left(\mathrm{n} \sim 1.5 \times 10^{18} \mathrm{~cm}^{-3}\right)$. A highly Si-doped GaAs contact layer caps the structure. This structure is somewhat non-optimized in that it does not employ a backsurface field, has no window layer, and no way to selectively remove the contact layer after processing.

The QE, current-voltage (IV), and capacitance-voltage (CV) measurements were completed using standard techniques. The internal QE was calculated from the measured external QE and reflectivity. The QE data presented below were corrected for grid shadowing to facilitate the comparison of devices with different grid designs. The IV curves yielded the short-circuit current $\left(\mathrm{J}_{\mathrm{sc}}\right)$ and open-circuit voltage $\left(\mathrm{V}_{\mathrm{oc}}\right)$, and the $\mathrm{CV}$ data provided the depletion width.

\section{RESULTS AND DISCUSSION}

\section{Quantum Efficiency}

Utilizing the lower impurity and vacancy concentrations possible using MBE growth, we succeeded in growing GalnNAs solar cells with depletion widths greater than $2 \mu \mathrm{m}$. These cells, with bandgaps down to $1.15 \mathrm{eV}$, show greatly enhanced short-circuit currents and QEs compared to reports in the literature. Figure 2 shows the QE measurements of several GalnNAs solar cells, displaying the difference between wide and narrow depletion widths at $E_{g} \sim 1.28 \mathrm{eV}$, as well as the QE from a cell with $E_{g} \sim 1.15 \mathrm{eV}$. The QE for a comparable GaAs cell is included for reference. The QEs for the samples with the wide depletion widths are, to our knowledge, the best reported for a GalnNAs sample. A report by Li et al on GalnNAs samples with similar bandgaps, but grown by MOCVD, shows maximum QEs below 0.7 [8]. Indeed, the best GalnNAs solar cells reported anywhere have had near band-edge QEs of approximately 0.8 [9].

Figure 3 shows the dependence of the QE (measured at an energy of $E_{g}+0.2 \mathrm{eV}$ ) on the depletion width. The data compares favorably to a simple model that assumes light is filtered by, but not collected by, the GaAs emitter and that the diffusion length of carriers in the GalnNAs base is negligible. The collection of photocarriers in the emitter is neglected because the emitter is not passivated, and most of the photocarriers recombine at the front surface. There are many data points that lie significantly above the model's

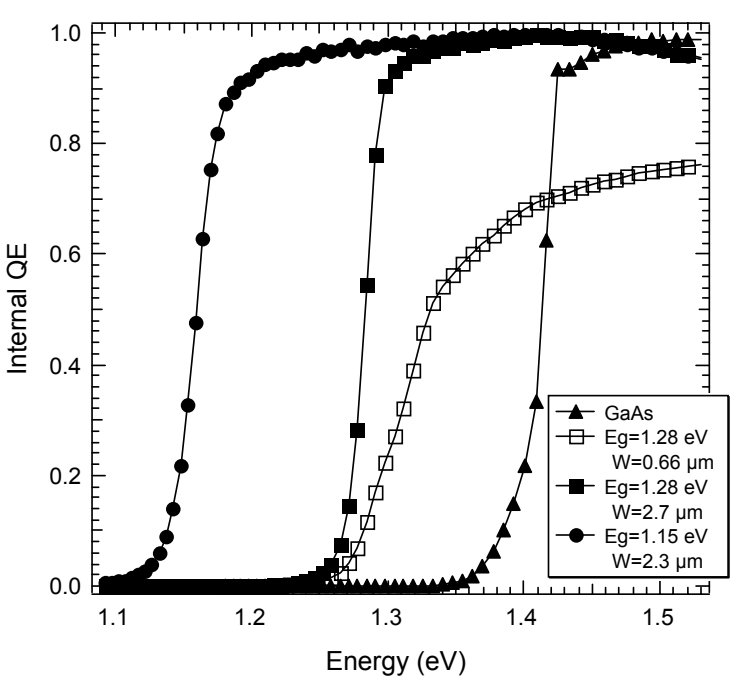

Figure 2. Comparison of QEs for similar samples with wide and short depletion widths. The data are corrected for the measured grid coverage to facilitate the comparison of devices with different grid designs.

predictions, possibly indicating some collection from diffusion in addition to the collection due to the drift of carriers in the field. The contribution of this non-zero diffusion length to the QE may be negligible when the depletion width is increased to more than $2 \mu \mathrm{m}$.

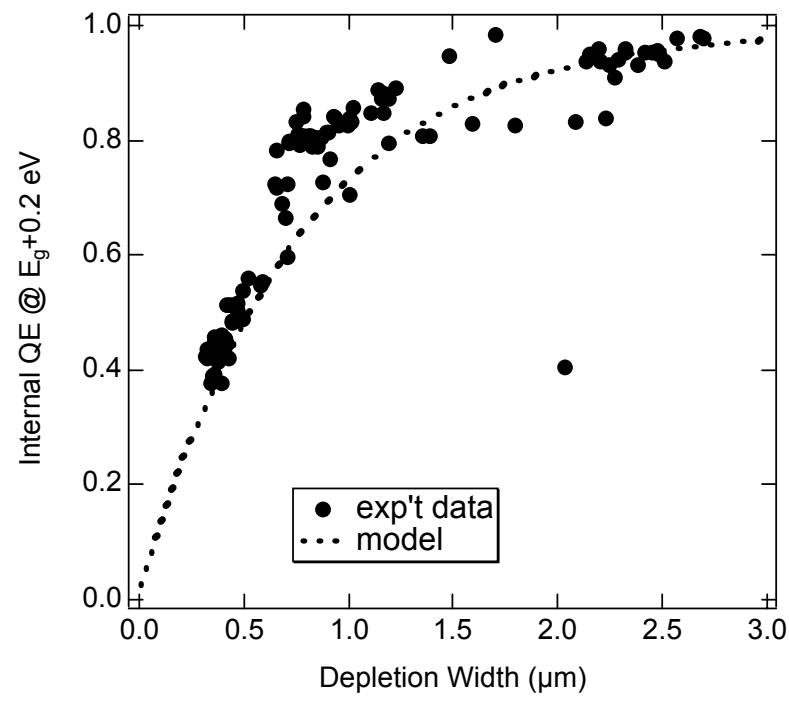

Figure 3. Compilation of $\mathrm{QE}$ values (measured at $E_{g}+0.2 \mathrm{eV}$ ) vs. depletion width. The data resemble the expected values from a simple model that assumes no contribution from diffusion or the emitter. The data are corrected for estimated grid coverage to facilitate the comparison of devices with different grid designs. 


\section{Concentrator Measurements}

The possibility exists that using a wide, intrinsically doped layer in a solar cell device will adversely effect the associated series resistance, especially under concentrator operation. To evaluate this issue, we measured the IV curves as a function of concentration for a 1.28-eV junction with a fully depleted base of width $3 \mu \mathrm{m}$ and doping $p=2 \times 10^{14} / \mathrm{cm}^{3}$. The IV curves were measured using a pulsed solar simulator, [10] with the sample nominally at $25^{\circ} \mathrm{C}$. Figure 4 shows the resulting $\mathrm{V}_{\text {oc }}$, the ideality factor $n$ as deduced from the slope of the $\mathrm{V}_{\text {oc }}$ curve, and the fill factor (FF) vs. $\mathrm{J}_{\mathrm{sc}}$. In the application with $\mathrm{GalnP}_{2}$ and $\mathrm{GaAs}$ top and middle cells, the desired one-sun current would be on the order of $14 \mathrm{~mA} / \mathrm{cm}^{2}$, i.e. a 500 -sun current of $7 \mathrm{~A} / \mathrm{cm}^{2}$ as

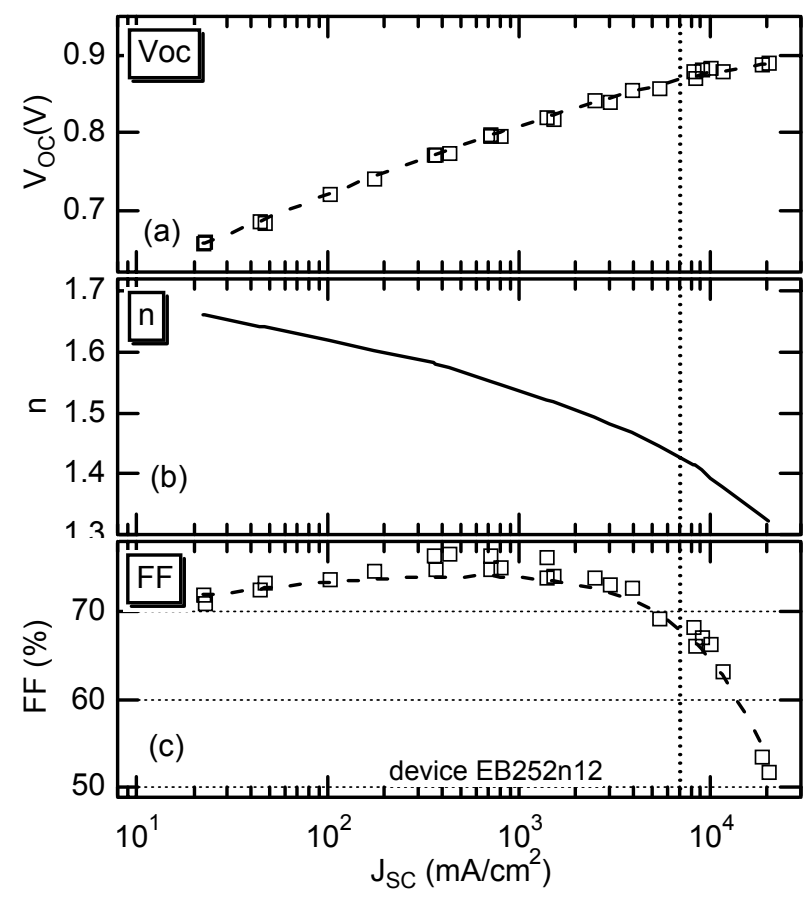

Figure 4. (a) $\mathrm{V}_{\mathrm{oc}}$, (b) ideality factor, $\mathrm{n}$, and (c) FF of a wide-depletion-width, 1.28-eV GalnNAs cell as a function of concentration. The dashed line in (c) is a fit to a seriesresistance model, with fit value $\mathrm{Rs}=1.1 \times 10^{-2} \Omega \mathrm{cm} 2$.

indicated by the vertical dotted line in the figure. At this concentration, Fig. 4c shows that FF is barely below its one-sun value, indicating that series resistance is not a significant factor at this concentration.

To be more quantitative, we fit the FF data by calculating FF for the standard diode equation with ideality factor $n$, including series resistance $R_{S}$ as the fit parameter, and scaled to the measured FF value at one sun. A very good fit is obtained with $R_{S}=1.1 \times 10^{-2} \Omega \mathrm{cm}^{2}$, as shown by the dashed line in Fig. 4c. This value for $R_{S}$ represents the sum of all the series resistances in the device, including not only the base resistance of interest but also resistances through the emitter, the grid fingers, and the grid-semiconductor contact. Separate measurements of these parameters indicate that together they total $2 \times 10^{-3} \Omega \mathrm{cm}^{2}$, so $R_{\mathrm{S}}$ due to the

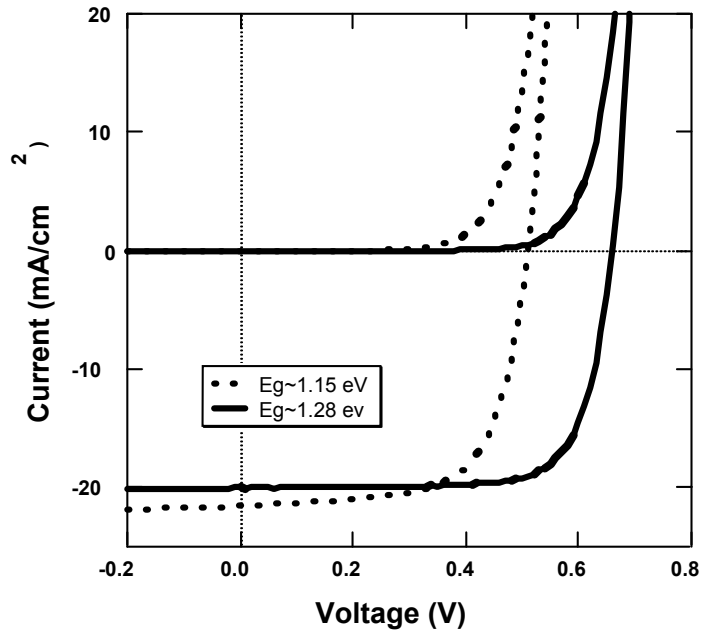

Figure 5. Light and dark IV curves for the widedepletion-width GalnNAs cells from Fig. 2 .

base alone is $R_{S}=9 \times 10^{-3} \Omega \mathrm{cm}^{2}$. At the 500 -sun current of $7 \mathrm{~A} / \mathrm{cm}^{2}$, the voltage drop across the base due to this $R_{S}$ is $0.063 \mathrm{~V}$. In other words, the wide-depletion-width device of Fig. 4 does not suffer significantly from series resistance across the base for concentrations at least as high as 500 suns.

\section{Open-Circuit Voltage}

Figure 5 shows light and dark IV curves for the widedepletion-width GalnNAs layers in Fig. 2. The measurements were performed without a GaAs filter. The difference between the bandgap and the $V_{\text {oc }}\left(E_{g}-V_{o c}\right)$ for these cells is $\sim 0.62 \mathrm{~V}$. Typically, $\mathrm{E}_{\mathrm{g}}-\mathrm{V}_{\text {oc }}$ is about $0.4-0.5 \mathrm{~V}$ for $\mathrm{GaAs}$ and GalnP $\mathrm{P}_{2}$, while GalnNAs cells are usually much closer to 0.6 $\mathrm{V}$, presumably due to some unidentified defect [11]. One concern with using a $\mathrm{p}-\mathrm{i}-\mathrm{n}$ structure is possible carrier recombination in the depletion region, lowering the $\mathrm{V}_{\mathrm{oc}}$, and perhaps the QE [12] of the cell. Additional decreases in the $V_{\text {oc }}$ would reduce the usefulness of GalnNAs in a 4-junction structure, whether or not the current is increased [4]. Promisingly, the $\mathrm{V}_{\text {oc }}$ 's for our cells degrade by less than $5 \%$ for depletion widths of several microns.

$\mathrm{W}$ would like to know what $\mathrm{V}_{\text {oc }}$ we can expect from a 1.0-eV GalnNAs solar cell. For one-sun applications, we could expect $\sim 0.4 \mathrm{~V}$, based on $\mathrm{E}_{\mathrm{g}}-\mathrm{V}_{\text {oc }} \sim 0.6$. Using the data in Fig. 4 and assuming the same value for $E_{g}-V_{o c}$, we estimate that a 1.0-eV junction would show $\mathrm{V}_{\text {oc }} \sim 0.6 \mathrm{~V}$ at 500 suns illumination. There is the possibility that these voltages will increase with an optimized cell structure.

It is important to note that the bandgaps of the samples in this study are only as low as $1.15 \mathrm{eV}$, much higher (that

Table 1. Photocurrent collected from GalnNAs layers for photons with energies below the GaAs band edge.

\begin{tabular}{|c|c|c|}
\hline$E_{g}(\mathrm{eV})$ & $\mathrm{AM0}\left(\mathrm{mA} / \mathrm{cm}^{2}\right)$ & Low AOD $\left(\mathrm{mA} / \mathrm{cm}^{2}\right)$ \\
\hline 1.28 & 3.15 & 2.16 \\
\hline 1.15 & 6.64 & 5.67 \\
\hline
\end{tabular}


is, much less nitrogen) than necessary for use in a currentmatched 4-junction structure. Table I shows the photocurrent collected from the GalnNAs junction (below the GaAs band edge) for two different spectra. Clearly, the bandgaps of these cells need to be pushed toward $1 \mathrm{eV}$, without significant degradation of the depletion width, to provide an increase in device efficiency for the 4-junction structure. It is possible that the addition of more nitrogen to these cells will adversely affect the background carrier concentrations, and hence the depletion widths. However, we are encouraged by the excellent QEs obtained for the bandgaps studied thus far.

\section{CONCLUSIONS}

High-quality GalnNAs has been sought for use in 4junction solar cells for several years. Although the photovoltages in this material are still lower than they ideally should be, we show here that the photocurrents are greatly increased with the use of an MBE-grown $p-i-n$ structure with a wide depletion region. Series resistance across the low-doped base does not significantly degrade concentrator performance up to at least 500 suns. With extension to lower bandgaps, these increased quantum efficiencies may provide the current needed for a higher-efficiency 4-junction $\mathrm{GalnP}_{2} / \mathrm{GaAs} / \mathrm{GalnNAs} / \mathrm{Ge}$ device.

\section{REFERENCES}

[1] S. R. Kurtz, D. Myers, and J. M. Olson, "Projected Performance of Three- and Four-Junction Devices using GaAs and GalnP," presented at 26th IEEE Photovoltaic Specialists Conference, Anaheim, 1997.

[2] J. F. Geisz, D. J. Friedman, J. M. Olson, S. R. Kurtz, and B. M. Keyes, "Photocurrent of $1 \mathrm{eV}$ GalnNAs lattice-matched to GaAs," J Cryst Growth, vol. 195, pp. 401408, 1998.

[3] S. R. Kurtz, A. A. Allerman, C. H. Seager, R. M. Sieg, and E. D. Jones, "Minority carrier diffusion, defects, and localization in InGaAsN, with 2\% nitrogen," Appl. Phys. Lett., vol. 77, pp. 400-402, 2000.

[4] D. J. Friedman and S. Kurtz, "Breakeven Criteria for the GalnNAs junction in GalnP/GaAs/GalnNAs/Ge fourjunction solar cells," Prog. Photovolt., vol. 10, pp. 331-344, 2002.

[5] S. Kurtz, R. Reedy, B. Keyes, G. D. Barber, J. F. Geisz, D. J. Friedman, W. E. McMahon, and J. M. Olson, "Evaluation of NF3 versus dimethylhydrazine as N sources for GaAsN," J Cryst Growth, vol. 234, pp. 323-326, 2002.

[6] A. Janotti, S. H. Wei, S. B. Zhang, S. Kurtz, and C. G. VandeWalle, "Interactions between nitrogen, hydrogen, and gallium vacancies in GaAs1-xNx alloys - art. no. 161201," Phys Rev B, vol. 6716, pp. 1201, 2003.

[7] A. J. Ptak, S. Kurtz, K. G. Lynn, and M. H. Weber, "Positron annihilation spectroscopy study of vacancies in GalnNAs," J vac Sci Technol B, vol. 22, pp. 1584, 2004.

[8] N. Y. Li, P. R. Sharps, M. Stan, F. Newman, J. S. Hills, H. Q. Hou, J. M. Gee, and D. J. Aiken, "Development of $1.25 \mathrm{eV}$ InGaAsN for Triple Junction Solar Cells," presented at 28th IEEE Photovoltaic Specialists Conference, Anchorage, Alaska, 2000.

[9] S. Kurtz, J. F. Geisz, D. J. Friedman, J. M. Olson, A. Duda, N. H. Karam, R. R. King, J. H. Ermer, and D. E. Joslin, "Modeling of Electron Diffusion Length in GalnAsN Solar Cells," presented at 28th IEEE Photovoltaic Specialists Conference, Anchorage, Alaska, 2000.

[10] J. Kiehl and K. Emery, "Characterization of Photovoltaic Concentrators," presented at DOE Solar Program Review Meeting, Denver, 2004.

[11] Sarah Kurtz, J.F. Geisz, D.J. Friedman, and A.J. Ptak, "Effect of nitrogen concentration on the performance of $\mathrm{Ga}(\mathrm{In}) \mathrm{As}(\mathrm{N})$ solar cells", paper submitted to the $31^{\text {st }}$ IEEE Photovoltaic Specialists Conference, 2005.

[12] D.J. Friedman, Sarah Kurtz, A.J. Ptak, and J.F. Geisz, "Analysis of depletion-region collection in GalnNAs solar cells", paper submitted to the $31^{\text {st }}$ IEEE Photovoltaic Specialists Conference, 2005. 


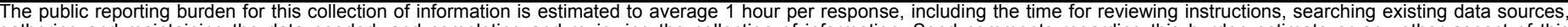

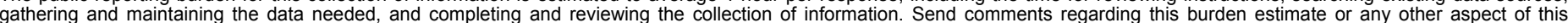

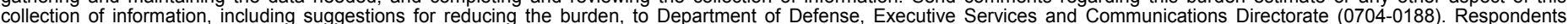

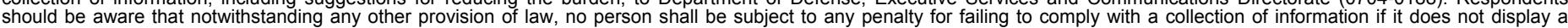

should be aware that notwithstanding

PLEASE DO NOT RETURN YOUR FORM TO THE ABOVE ORGANIZATION.

\section{REPORT DATE (DD-MM-YYYY) \\ February 2005 \\ 2. REPORT TYPE \\ Conference Paper}

4. TITLE AND SUBTITLE

Enhanced-Depletion-Width GalnNAs Solar Cells Grown

by Molecular-Beam Epitaxy

\section{DATES COVERED (From - To)} 3-7 January 2005

5a. CONTRACT NUMBER

DE-AC36-99-GO10337

5b. GRANT NUMBER

5c. PROGRAM ELEMENT NUMBER

5d. PROJECT NUMBER

NREL/CP-520-37479

5e. TASK NUMBER

PVA54401

5f. WORK UNIT NUMBER
7. PERFORMING ORGANIZATION NAME(S) AND ADDRESS(ES)

National Renewable Energy Laboratory

1617 Cole Blvd.

Golden, CO 80401-3393
8. PERFORMING ORGANIZATION REPORT NUMBER

NREL/CP-520-37479

9. SPONSORING/MONITORING AGENCY NAME(S) AND ADDRESS(ES)

10. SPONSOR/MONITOR'S ACRONYM(S) NREL

11. SPONSORING/MONITORING AGENCY REPORT NUMBER

12. DISTRIBUTION AVAILABILITY STATEMENT

National Technical Information Service

U.S. Department of Commerce

5285 Port Royal Road

Springfield, VA 22161

13. SUPPLEMENTARY NOTES

\section{ABSTRACT (Maximum 200 Words)}

GalnNAs, potentially useful in a 4-junction GalnP $2 / G a A s / G a l n N A s / G e$ solar cell, suffers from very low minority-carrier collection lengths. To date, the currents available from GalnNAs solar cells are not high enough to increase the efficiency of a 3-junction device by adding this fourth junction. Here, we grow p-i-n GalnNAs solar cells by molecularbeam epitaxy with wide, intrinsic base layers and internal quantum efficiencies near 1.0. If similar 1.0-eV GalnNAs junctions can be successfully integrated into the 3-junction structure, the resulting 4-junction cell would have a higher efficiency.

\section{SUBJECT TERMS}

PV; enhanced depletion; solar cell; quantum efficiency; concentrator measurements; open-circuit voltage; bandgap; molecular-beam epitaxy;

\begin{tabular}{|c|c|c|}
\hline \multicolumn{3}{|c|}{ 16. SECURITY CLASSIFICATION OF: } \\
\hline $\begin{array}{l}\text { a. REPORT } \\
\text { Unclassified }\end{array}$ & $\begin{array}{l}\text { b. ABSTRACT } \\
\text { Unclassified }\end{array}$ & $\begin{array}{l}\text { c. THIS PAGE } \\
\text { Unclassified }\end{array}$ \\
\hline
\end{tabular}

\begin{tabular}{c|c} 
17. LIMITATION \\
OF ABSTRACT \\
UL
\end{tabular}
19a. NAME OF RESPONSIBLE PERSON 19b. TELEPHONE NUMBER (Include area code) 